International Water Resources Association

Water International, Volume 29, Number 1, Pages 11-19, March 2004

\title{
From Marrakech Through The Hague to Kyoto: Has the Global Debate on Water Reached a Dead End?
}

\author{
Part Two
}

\begin{abstract}
Salman M. A. Salman, Member IWRA, Washington DC, USA
Abstract: Although the first World Water Forum was held in 1997, realization by the world community of the vast array of problems facing the water sector dates back to the 1970s. Indeed, the Mar del Plata Water Conference held in 1977 can be considered the first world water forum. Since that time, a series of international conferences, including the three world water forums that were held in Marrakech, The Hague and Kyoto, have been organized to discuss the existing and emerging water problems. Such conferences and forums have debated the major issues regarding management and development of water resources and have adopted a number of resolutions, declarations, and action plans. The debate on many of those issues has sharpened in recent years and the resolutions, declarations, and action plans have multiplied. This article discusses the basic elements of the debate and the areas of differences between the various groups, and it assesses the efficacy and impact of the resolutions, declarations, and action plans adopted at those conferences.

This is the second of a two-part article, the first of which was published in the previous issue of Water International, Volume 28, Number 4.

Keywords: Abuja Declaration, Dublin Statement, European Water Framework Directive, Global Water Partnership, Johannesburg Summit, Kyoto Ministerial Declaration, Mar del Plata Water Conference, Marrakech Declaration, Millennium Development Goals, New Delhi Statement, Rio Summit, Stockholm Declaration, The Hague Ministerial Declaration, United Nations Convention on the Law of the Non-Navigational Uses of International Watercourses, World Commission for Water in the $21^{\text {st }}$ Century, World Commission on Dams, World Panel on Financing Water Infrastructure, World Water Council
\end{abstract}

\section{Introduction}

The first part of this article traced the earlier attempts of the world community to address the existing and emerging problems in the water sector. It discussed the outcome of the Mar del Plata United Nations Water Conference and the reasons behind the lack of success of the International Drinking Water Supply and Sanitation Decade. It also outlined the events leading to the establishment of the World Water Council and the Global Water Partnership, discussed the objectives of both, and analyzed the debate and the resolutions issued at the end of the first and second world water forums. The first part also discussed the outcome of the United Nations Millennium Summit held in New York in September 2000 and the Millennium Development Goals. Furthermore, it discussed and analyzed the background, context, and aftermath of the Report of the World Commission of Dams released in London in No- vember of the same year, as well as the United Nations resolution proclaiming the year 2003 as the "International Year of Freshwater."

This part of the article will continue the discussion and analysis of both the regional as well as the subsequent international attempts at addressing the existing and emerging water issues, and the manner in which those issues have been dealt with. It will analyze the basic elements of the debate and the resolutions and declarations issued at the different forums and conferences, and it will pose and attempt to answer the question of whether such debate and resolutions are leading anywhere.

\section{Regional Attempts Addressing the Water Resources Problems}

The attempts for dealing with the water resources problems have not been confined to the global efforts. Three regional developments that flow into global efforts 
to deal with water resources issues are worth mentioning. In December 2000, the European Water Framework Directive entered into force. This Directive constitutes an innovative approach to the development of water policy of the European Community. It rationalizes the Community's highly fragmented water legislation under one coherent legal framework which takes an integrated approach towards the management and protection of water resources in the Member States of the Community.

Water is one of the most comprehensively regulated areas of the Community. The legal instrument most frequently used in this respect is the so-called "directive." During the last 25 years, the Community has adopted a number of water-related directives aimed at specific uses, processes, industries, or substances. In the course of this process, it became increasingly apparent that the different pieces of the Community water legislation were fairly unrelated and represented a patchwork of incoherent sometimes even contradictory - legal instruments that were fragmented both in objectives and means. Hence, the Community decided on the adoption of the Water Framework Directive. The Directive takes a holistic and comprehensive approach towards water management as it covers the relevant components of water: namely, inland surface waters, groundwater, transitional waters, and coastal water. For the first time, surface waters and groundwater are managed in an integrated manner at the European level. Therefore, it can be argued that the Directive functions as a unique interface between the supranational law of the European Community, national water law, as well as international law on transboundary fresh water resources. Indeed, the potential of the Water Framework Directive to exert influence on conventions and treaties on international water resources involving both Members and nonMembers is considerable. This will in turn reshape international water law in Europe by confirming the Directive regional approach to the management of transboundary water resources throughout Europe (Reichert, 2004).

A reference should also be made to the work of the United Nations Economic Commission for Europe in the field of shared water resources. One of the responsibilities of the Commission, whose membership is larger than the European Union and includes 55 countries, relates to transboundary water. In 1992 the Commission adopted the "Convention on the Protection and Use of Transboundary Watercourses and International Lakes" that entered into force in October 1996. The aims of the Convention include protection of transboundary waters (including surface and groundwater) by preventing, controlling, and reducing pollution; ecologically sound and rational management of transboundary waters; reasonable and equitable use of transboundary waters; and conservation of the ecosystem. The Convention explicitly recognizes the need to apply the precautionary principle, the polluter pays principle, and the inter-generation equity principle (Bosnjakovic, 1998).
Another regional effort that is worth assessing is the "Abuja Ministerial Declaration on Water - A Key to Sustainable Development in Africa" which was adopted by 45 African Ministers responsible for water in April 2002. Pursuant to the Declaration, the African Ministerial Conference on Water (AMCOW) was launched. The preamble to the Declaration underscores the fact that a decade after the United Nations Conference on Environment and Development (the Rio Summit), more Africans lack access to safe water and sanitation, and that almost half the people of the Continent, particularly women and children, suffer from water related diseases (Salman, 2001). It is to be noted in this connection that only about 58 percent of the population in Africa has access to safe water (NEPAD, 2001).

The Declaration directs AMCOW to strive to strengthen inter-governmental cooperation in order to halt and reverse the water crisis and sanitation problems in Africa. The Declaration further states that AMCOW will monitor progress in the implementation of major regional and global water resources and water supply and sanitation initiatives, and will review progress in the implementation of the commitments set forth in the key international arrangements for the provision of financial resources and technology transfer in support of the water sector reforms in Africa. It also states that AMCOW will consider information provided by the African Water Ministers regarding the best practices in policy reforms in the water and sanitation sector at the country level, as well as information on the progress made in the implementation of the inter-governmental agreements. The Declaration refers to Chapter 18 (on Fresh Water Resources) of Agenda 21 of the Rio Summit, and states that AMCOW shall support measures for regional inter-governmental dialogue on the implementation of Chapter 18 for the purpose of recommending strategies needed to strengthen implementation.

The Abuja Declaration is quite specific with regard to institutional arrangements, as it establishes a Conference, a Bureau, and a Secretariat for AMCOW. However, the Declaration lacks specificity on policies and actions. Not even the basic policies on water resources management that were adopted at Dublin and Rio in 1992 are being embodied, or referred to, in it. The Declaration also fails to set specific actions for implementation in the coming years or decades. The provisions of the Declaration fall more in the "best effort" category and uses such phrases as "strive to strengthen" and "support measures which encourage stronger and better performing institutional arrangements." The role of AMCOW is not a proactive one, and it includes functions such as "receiving and analyzing reports and information," and "considering, where appropriate information regarding progress made in implementation of agreements." Thus, although the Abuja Declaration underscored the problems that the African Continent is facing in its water resources sector, the Declaration has not provided the necessary measurable and monitorable action plans that are needed to address such 
problems (Salman, 2002). In that connection, the Declaration is somehow similar to the Hague Ministerial Declaration. Neither of the two has set any goals nor included any measurable actions.

Thus, the European Community and the Economic Commission for Europe have followed the strict route of legally binding instruments for addressing water resources issues. On the other hand, the African countries' approach has been through a political statement with little practical effects and no legal effects whatsoever.

\section{Rio Plus Ten in Johannesburg: Back to the Future?}

The year 2001 was not as busy as 2000 with international conferences, workshops, declarations, and resolutions on water resources. The debate on the outcome of the Hague Forum and on the Report of the World Commission on Dams, both of which took place in 2000, occupied a good part of the time and energies of the water professionals in 2001. It was only in December 2001 that two major events took place. The first was the United Nations General Assembly resolution on "Status of Preparations for the International Year of Freshwater 2003," adopted in December 2001. The General Assembly referred to its earlier resolution of December 2000 proclaiming 2003 as the International Year of Freshwater, as well as the millennium development goal of reducing by half, between the years 2000 and 2015, the proportion of people who are unable to reach or afford safe drinking water. It also noted the efforts for the preparations of the Third World Water Forum to be held in Japan in March 2003 and for the elaboration of the World Water Development Report to be released there, and it welcomed the activities in preparation for the observance of the International Year of Freshwater. The Resolution went on to encourage all Member States, the United Nations system, and other groups to work towards raising awareness of the essential importance of freshwater resources for satisfying basic human needs, for health and food production, for preservation of ecosystems, as well as for economic and social development in general, and for promoting action at the local, national, regional, and international levels.

The earlier Resolution declaring 2003 as the International Year of Freshwater invited the Subcommittee on Water Resources of the Administrative Committee on Coordination of the United Nations to serve as the coordinating entity for the Year. As a result, the United Nations system has undertaken the responsibility of conducting a World Water Assessment Programme (WWAP) coordinated by the United Nations Educational, Scientific, and Cultural Organization (UNESCO). The World Water Development Report which would be released at the Kyoto Water Forum, as we shall see, is the key outcome of this collaborative effort and a major contribution to the International Year of Freshwater and the Kyoto Water Forum.
The other event that took place was the Ministerial Session of the International Conference on Freshwater that was held in Bonn, Germany in December 2001. The purpose of the gathering was to assess the progress achieved in implementing Agenda 21 of the Rio Summit and to discuss actions required to increase water security and to achieve sustainable management of water resources. Another purpose for this meeting was to pave the way for the World Summit on Sustainable Development that was to be held in Johannesburg in August 2002.

The Ministerial Declaration of the Bonn meeting reiterated what has become by now an obligatory preamble to all the water meetings: the gloomy fact that 1.2 billion people have no access to safe drinking water, and 2.5 billion have no access to proper sanitation. The Bonn Declaration pronounced safe and sufficient water and sanitation as basic human needs and confirmed the resolve to attain the target set by the United Nations Millennium Summit of halving by the year 2015 the proportion of people unable to reach or afford safe drinking water. The Declaration dealt with five major areas: governance, funding gap, role of international community, capacity building and technology transfer, and gender. Finally, the Declaration urged the World Summit on Sustainable Development to take account of the outcome of the Bonn Conference.

Three observations can be offered in connection with the Bonn Conference. The Conference was planned as a preparatory meeting to the World Summit on Sustainable Development that would be held in Johannesburg in September 2002. As such, the Bonn Conference was supposed to play the same role for the Johannesburg summit as that of the Dublin meeting for the Rio Summit. The Bonn Conference declared safe drinking water and sanitation as "basic human needs," a pronouncement short of declaring them as a "basic human right." This is an important distinction, but would still fuel the debate on this issue a year later, as we shall see. The third observation is the use of the term "governance" by the Declaration. This is a term that is difficult to define. Yet, henceforth, the issue of "water governance" would occupy a prominent place in the international debate on water (Rogers and Hall, 2003).

The World Summit on Sustainable Development took place September 2-4, 2002 in Johannesburg. The Johannesburg Declaration on Sustainable Development was issued at the end of the Summit. Similar to the Rio Summit, the Johannesburg Summit also took place in a developing country, and both dealt with wider issues, of which water was but one. However, whereas the Rio Declaration is a focused document that addresses specific issues in a relatively precise language, incorporating a certain principle in each paragraph of the Declaration, the Johannesburg Declaration is a lengthy and imprecise document. It is a replication of imprecision and lack of specificity of The Hague and Bonn Declarations; this is to be repeated again, as we shall see, in the Kyoto Declaration six months later. 
The participants in the Johannesburg Summit committed themselves to building a humane, equitable, and caring global society cognizant of the need for human dignity for all. They also assumed a collective responsibility to advance and strengthen the inter-dependent and mutually reinforcing pillars of sustainable development - economic development, social development, and environment protection - at the local, national, regional, and global levels.

The Declaration referred to the Stockholm Conference, to the Rio Earth Summit, Agenda 21, and to the Rio Declaration and its principles and reaffirmed the commitment to those principles. The Declaration recognized that poverty eradication, changing consumption and production patterns, and protecting and managing the natural resource base for economic development are overarching objectives of, and essential requirements for, sustainable development. It took note of the fact that air, water, and marine pollution continue to rob millions of a decent life.

However, under the sub-heading "commitment to sustainable development" the Declaration sank into generalizations and lack of specificity. It urged the promotion of dialogue and cooperation among the world civilizations; it welcomed the focus on the indivisibility of human dignity; it reaffirmed the pledge to place particular focus on, and give priority attention to, the fight against the world-wide conditions that pose severe threats to sustainable development; and urged the developed countries to make concrete efforts towards the internationally agreed levels of Official Development Assistance. The Declaration committed the participants in the Summit to the "Johannesburg Plan of Implementation" that was also agreed upon and issued at the end of the Summit. It is noteworthy that the plan was called "Plan of Implementation," as opposed to the title "Action Plan" used in the Mar del Plata, and "Programme of Action" used in Rio. Thus, the emphasis was more on implementation than on planning.

This Plan is a fairly detailed document and represents, in a way, the equivalent of Agenda 21 of the Rio Summit. However, it is far less detailed than Agenda 21, and, unlike Agenda 21, it is not organized by subject matters. Although water has not occupied a prominent place in the Johannesburg Declaration where it was only mentioned twice, it was dealt with in a detailed, albeit general, manner in the Plan. The sections on "Poverty Eradication" and "Protecting and Managing the Natural Resource Base of Economic and Social Development" both made numerous references to water. Both reiterate the millennium development goal to halve by the year 2015 the proportion of people who are unable to reach or to afford safe drinking water. However, the Plan went further and added as a goal decreasing by a half the proportion of people who do not have access to basic sanitation and called for integration of sanitation into water resources management strategies. This is certainly a welcome rectification to the unfortunate omission of sanitation from the Millennium Development Goals, as discussed earlier, and a necessary action to confirm the integration of the two components.

The Section on "Protecting and Managing the Natural Resource Base" repeated the usual calls for strategies, which would include targets for protecting the eco-system, achieving integrated water resources management, and mobilizing additional resources. It also called for facilitating participation, including by women, as well as providing new and additional financial resources and innovative technologies to implement Chapter 18 of Agenda 21. However, the Section set the year 2005 as the target date for developing integrated water resources management and efficiency plans and for addressing water shortage through a number of actions including developing and implementing strategies, plans, and programs and employing the full range of policy instruments for that purpose. It called for the adoption of policies and the implementation of laws that guarantee well defined and enforceable water rights. Moreover, the Section recommended certain actions in the field of water resources under the initiatives for each region of the world.

The Plan addressed the issue of access to safe water, though not as clearly and directly as in some of the previous declarations and resolutions. The Plan recommended employing the full range of policy instruments, including cost recovery of water services, "without cost recovery objectives becoming a barrier to access to safe water by poor people."

However, the issue of the right to access to safe water attained a major gain in November 2002 when the United Nations Committee on Economic, Social, and Cultural Rights declared safe and secure drinking water a human right. The Committee made this declaration in the form of a General Comment. General Comments by the Committee are interpretations of specific articles of the International Covenant on Economic, Social and Cultural Rights that was adopted by the United Nations in 1966, signed immediately thereafter, and entered into force in 1976. Although the Covenant does not refer specifically to "water," the Committee determined that the right to water is clearly derived from Article 11 of the Covenant. That Article provides that the Parties "recognize the right of everyone to an adequate standard of living for himself and his family, including adequate food, clothing and housing, and to the continuous improvement of living conditions." The General Comment states that the human right to drinking water is fundamental for life and health, and that sufficient and safe drinking water is a precondition for the realization of all human rights. The Comment goes on to define water as a social and cultural good and not primarily as an economic commodity. The adoption of this Comment in November 2002 appears more as a conscious, rather than coincidental, act to initiate the United Nations International Year of Freshwater in 2003.

While this proclamation is no doubt a landmark, it should be clarified that under the Covenant, the State Parties to the Covenant (now numbering 145 states) are un- 
der no obligation to implement the provisions of the Covenant immediately. The obligations are characterized as "progressive," such that the State Parties are only bound to take steps to the maximum of their available resources, with the view of achieving over time the full realization of the rights recognized under the Covenant. As such the State Parties have a constant and continuing duty to progressively ensure that everyone has access to safe and secure drinking water and sanitation facilities, equitably and without discrimination.

It should be recalled in this connection that the only universal agreement that expressly mentions the right to water is the Convention of the Rights of the Child. This Convention was adopted in 1989 and entered into force in 1990. The Parties to the Convention now number 191 countries. Article 24 of the Convention obliges the State Parties to take appropriate measures to combat disease and malnutrition through, inter alia "the provision of adequate nutritious foods and clean drinking-water."

It is clear that the pendulum has swung in favor of the proponents of the concept of the human right to water. The adoption of this General Comment will certainly intensify the debate on the concept of the human right to water and its practical and legal implications. The stage has now been set for a major debate on the ramifications of this Comment. The Kyoto Water Forum, as we shall see in the next section, would be the dueling fields for the debate on the issue as well as its ramifications.

\section{The Kyoto Water Forum: A Climax or Anticlimax?}

The preceding section provided an overview of the major international developments in the water sector after The Hague Second Water Forum, leading to the Third Water Forum. Those events included the United Nations Millennium Summit in September 2000 and the adoption of the Millennium Development Goals; the release of the Report of the World Commission on Dams in November of that year; and the adoption in December 2000 by the United Nations General Assembly of the Resolution proclaiming 2003 as the International Year of Freshwater. The year 2001 witnessed the Ministerial Session of the International Conference on Freshwater in Bonn and the adoption of the Bonn Ministerial Declaration. The year 2002 was the year for "Rio Plus Ten" that was translated in the Johannesburg World Summit on Sustainable Development and the adoption of the Johannesburg Declaration on Sustainable Development. Clearly, water resources were high on the agenda of the international debate during those three years. Those three years were also punctuated by regional activities on water issues, including the adoption of the European Water Framework Directive in 2000 and the Abuja Ministerial Declaration on Water in 2002. Another highlight of that year was the proclamation of water as a human right by the Committee on Economic, Social and Cultural Rights.
All those events, with their resolutions and declarations, have paved the road to the preparations for, and have indeed provided the main elements of the debate during, the Third World Water Forum that took place in Kyoto from March 16-23, 2003. As the number of participants in that Forum has multiplied to more than 12,000, the events had to be spread over the cities of Osaka and Shiga, in addition to Kyoto.

The highlights of the Forum were the release of three reports. The first report was the United Nations World Water Development Report which was prepared by the World Water Assessment Program, a combination of effort of twenty-three United Nations agencies and conventions secretariat, under the coordination of UNESCO. The Report offers a comprehensive assessment of the state of freshwater resources in the world today. It also addresses eleven global challenges to water resources, ranging from population growth and the need for food and energy to the issue of water governance that involves the aspects of recognizing and valuing the many faces of water, as well as collective responsibility thereon (World Water Assessment Programme, 2003).

The second report was the World Water Council's World Water Actions "Making Water Flow for All." The report includes an analysis of the actions and commitments by both governments and organizations in the water sector since The Hague Water Forum, when the World Water Vision was presented by the World Water Council and the World Commission for Water in the $21^{\text {st }}$ Century. This report was meant as an input to the Ministerial Conference of the Kyoto Forum (World Water Council, 2003a).

The third one, which was quite controversial, was the Report of the World Panel on Financing Water Infrastructure, "Financing Water for All." The Panel, sponsored by the World Water Council, the Third World Water Forum, and the Global Water Partnership, was headed by Mr. Michel Camdessus (a former Managing Director of the International Monetary Fund - IMF), and included nineteen other members, mainly from the multilateral development banks and the private sector. Its mandate was to suggest ways of identifying the financial resources for addressing the needs of the states in the water sector, thus helping achieve the millennium development goal with regard to access to water. The Panel's main recommendation was that financial flows need at least to double (from an annual figure of $\$ 75$ billion today, to $\$ 180$ billion) and would have to come from financial markets, from water authorities themselves through tariffs, from multilateral financial institutions, from governments, and from public development aid. The Panel's report went on to make eleven recommendations for dealing with the water problems, including: reforming of the sector institutions, delegation of responsibility for water resources to local bodies with enough power to make decisions, making cost recovery sustainable, and addressing the issue of sovereign risk on projects, including foreign exchange risks so as to at- 
tract international loans and equity (World Water Council, 2003b). Like the World Commission for Water in the $21^{\text {st }}$ Century and the World Commission on Dams, the World Panel on Financing Water Infrastructure was disbanded after it presented its report at Kyoto. The legacy of the Panel will likely end up falling somewhere between that of the World Commission for Water, and the World Commission on Dams; not totally forgotten, but not fully remembered.

The first two reports - the World Water Development Report, and the World Water Actions - did not generate any controversy. However, the Panel's main recommendation relating to a major role for the private sector was bound to raise a lot of criticism by those who opposed such a role; indeed it has generated a major controversy. In addition to the highlighted role of the private sector, the issues of dams, and the related issues of the concept of a human right to water and international trade in water, were the main source of controversy at Kyoto. It should be emphasized, however, that this is not the first time for debating those issues. Such debate did take place in The Hague in 2000 and has been taking place, to a limited extent, in the annual Stockholm Symposium and in the many regional and academic workshops and conferences on water since the mid-1990s. However, the sheer number of participants in the Kyoto Forum and the diversified views they represented made the debate louder, sometimes acrimonious, and the views more polarized.

The polarization of views on those issues was also apparent in the Kyoto Ministerial Declaration. Because of such diversified and polarized views, it is not surprising that the Ministerial Declaration issued at the end of the Forum was awash in compromises and generalizations and lacking in specificity. The Ministers and Head of Delegations agreed to promote integrated water resources management, ensure good governance, and explore the full range of financing arrangements. They affirmed the necessity for countries to better coordinate monitoring and assessment systems and encouraged promotion of cooperation between riparian states on shared watercourses. They called on each country to develop strategies to achieve the millennium development goal to halve the population of people without access to safe drinking water by 2015 and encouraged studies for innovative technologies to assist with attaining this goal. The Declaration also urged the countries to review and establish appropriate legislative frameworks for the protection and sustainable use of water resources and for prevention of pollution, and to cooperate to minimize the damage caused by disasters.

The Ministerial Declaration did not make an explicit reference to dams. Yet it enumerated a number of means for improvement of agricultural water management, which included water storage. It also recognized the role of hydropower as one of the renewable and clean energy sources, whose potential should be realized in an environmentally and socially equitable manner. It is also notewor- thy that the Declaration, on the issue of financing of water infrastructure, gave a lukewarm reference to the Camdessus Report, only taking note of the Report, although in another paragraph the Declaration recommended exploring the full range of financing arrangements including private sector participation in line with "national policies and priorities." Moreover, the Declaration suggested that funds should be raised by adopting cost recovery approaches "which suit local climatic, environmental and social conditions, and the 'polluter-pays' principle, with due consideration to the poor."

The failure of the Kyoto Declaration to endorse the Camdessus Report is somehow similar to the failure of the Hague Declaration to endorse the vision recommended by the World Commission for Water in the $21^{\text {st }}$ Century. In both instances, the issues were too difficult and controversial for the participant ministers to make a commitment upon.

Thus, the Kyoto Ministerial Declaration attempted to walk a middle road on the contentious issues that were debated at the Forum. The result was a statement that attempted to please everybody. Moreover, the Declaration had little, if any, specific and measurable actions. It was, by and large, a replication of The Hague, Bonn, and Abuja Declarations. Thus, it was bound to please nobody.

\section{The Debate and Resolutions: Are They Leading Anywhere?}

The water forums, conferences, and workshops that were held during the last ten years share, as we have seen, two characteristics. The first characteristic is an extensive debate on dams, the role of the private sector in water resources, international trade in water and the issue of the human right to water. The debate on those issues which reached its epic at The Hague continued in the conferences that followed and culminated at Kyoto where it became louder and sometimes acrimonious. The second characteristic is the issuance at the end of each of those meetings of a resolution or a declaration and sometimes a detailed action plan, which attempts to draw a road map for dealing with the current and emerging water problems. Many of the major cities of the world have their names, by now, attached to a specific resolution, declaration, or action plan.

The World Commission on Dams is long gone, but certainly not forgotten, especially with the process being continued through UNEP Dams and Development Project. The debate on dams has no doubt been the loudest and most acrimonious. Dam proponents underscore the desperate need for water storage in most developing countries to fight drought and expand irrigation for food production for the ever-increasing population. They also stress the need for controlling floods, and for generation of hydropower as a clean and cheaper source for energy. The opponents, on the other hand, point at the high environmental and social costs of dams and the loss of 
biodiversity and forests. They draw attention to the millions who have been displaced and not resettled or rehabilitated properly, including indigenous peoples, and who have also lost their water rights because of dams. They also raise arguments on what they consider as other available and viable alternatives to dams. For them, the failures of the past establish a strong case against dams that is difficult to rebut.

On the issue of private sector participation in water resources management, the proponents highlight the Report of the World Panel which cited the annually projected cost of providing water as $\$ 180$ billion, from the current figure of $\$ 75$ billion, and indicate that the main source for such funding is the private sector. They point at what they consider the efficiency gains and market discipline associated with the participation of the private sector. They also argue, with regard to the issue of the human right to water, that this right does not mean that water should be provided free of charge, nor does it affect the principle of cost recovery. On the issue of international trade in water, they stress the fact that certain countries are already buying water from other countries because this is the cheapest alternative available to them. The opponents, on the other hand, insist that water is a social good and should not be a commodity for profit. They enumerate the costs to the poor and to the environment if water or water services were to be privatized and argue vehemently that the rural population, who constitute the bulk of the people in the developing world, will simply not be able to afford the cost of privately provided water. The answer to privatization for them would be participation of the users in water management through democratically constituted water users' associations. They also cite the cases of Cochabamba, Tucuman, and Buenos Aires, where disputes over the concession agreements erupted with the private sector in Bolivia and Argentina and ended in an arbitral tribunal. They point in this connection to the absence of an effective legal and regulatory framework, as well as the weak capacity, in most developing countries, for dealing with the private sector. And armed with the General Comment of the Committee on Economic, Social and Cultural Rights proclaiming water as a human right, they claim that this right would be severely undermined if the private sector is given any role in water management. They similarly tie the issue of international trade in water to the attempts to make water a commodity for profit.

Thus, the debate on those issues has become repetitive, and perhaps even ideological, and the failure to reach a middle ground has become quite apparent and persistent. This debate has simply become the dialogue of the deaf. The resolutions and declarations that are adopted at the end of each of those conferences and forums have attempted to walk the middle road on those issues, and ended up with a compromise, awash in generalizations, that pleased neither side.

Moreover, we should remember that those resolutions and declarations are simply political statements with no legally binding effects on the countries adopting them. They could at best help influence policies and legislations in those countries. The same would have to be said about the action and implementation plans. They are simply targets that the states may or may not meet any part thereof, without peril. The NGOs, civil society organizations, and academic circles may try to use such resolutions, declarations, and action plans to strengthen their arguments, but they simply do not provide them with legally enforceable instruments.

In this connection, it is important to distinguish those resolutions and declarations from the legally binding and enforceable conventions and multilateral treaties. The European Water Framework Directive and the United Nations Economic Commission for Europe Convention on the Protection and Use of Transboundary Rivers and International Lakes are both legally binding and enforceable instruments. Indeed, in April 2003, the European Commission sent formal requests to France and the United Kingdom asking them to comply with rulings issued by the European Court of Justice in connection with the failure of both countries to comply with water quality standards set under the European Water Framework Directive. Failure to comply with such rulings could result in substantial fines.

In parallel to this, the United Nations Watercourses Convention, despite its adoption by the United Nations General Assembly in May 1997 by a vote of 103 countries, has not yet entered into force and effect (Tanzi and Arcari, 2001; McCaffrey, 2002). It requires 35 instruments of ratification to do so. At the time of writing this article only 12 countries have ratified the Convention; more than six years after its adoption by the United Nations General Assembly. Although it has been argued that the main elements of the UN Watercourses Convention represent customary international water law, the Convention itself is not yet a legally binding instrument.

\section{Conclusion}

The developments discussed above demonstrate an unequivocal realization by the world community of the seriousness and urgency of the problems facing fresh water resources. However, the different conferences and forums that were held to address those problems have not lived up to those challenges. They have been consumed by endless debates on dams, the role of the private sector, trade on water, and the issue of the human right to water. The numerous resolutions and declarations adopted at those conferences are awash in generalizations and compromising language, reflecting a clear inability to reach an agreement on any of those issues. Moreover, those resolutions and declarations, by and large, lack specific measurable actions and programs.

In the few instances where actions are specific, the political will for implementing them, and for building con- 
sensus in the area of water resources management, is clearly lacking. As may be recalled, Chapter 18 of the "Programme of Action for Sustainable Development" of the Rio Summit called for designing and initiating by the year 2000 costed and targeted national action programs, and putting in place appropriate institutional structures and regulatory frameworks. Yet, 2000 came and passed, and the issue of compliance, or non-compliance, with this recommendation never arose in any of the conferences and forums that were held since that year. It should also be mentioned that the millennium development goal of reducing child mortality by two-thirds is in a way a reiteration of the agreements adopted under the Convention of the Rights of the Child which called for the attainment of the highest standard of health for children and for combating disease and malnutrition. That Convention entered into force in 1990, and by now has 191 countries as parties. Yet, 13 years after its entry into force, not much change has taken place in the status of children in the developing countries. Past failures raise legitimate questions and concerns about the prospects for future success.

It is also noticeable that there is a steady proliferation of international agencies working on water resources, and the relationship between those different agencies does not seem to be well defined. Their work edges on competition, and some of the work is characterized by duplication, despite the attempts that have been made at cooperation and coordination. Indeed, a number of resolutions and declarations, as mentioned before, have called for close coordination between the different United Nations agencies working in the area of water resources. As discussed earlier also, the Hague Ministerial Declaration called specifically on the Secretary General of the United Nations to further strengthen cooperation within the United Nations systems.

Another noticeable fact is the repeated mention in the different resolutions and declarations of the need for cooperation on shared watercourses. However, the political will for following words with deeds does not seem to exist in many countries. The lack of political will is manifest in the failure of the world community to bring the United Nations Convention on the Law of the Non-Navigational Uses of International Watercourses into force and effect, more than six years after its adoption by the UN General Assembly. This is in spite of the fact that the Convention has been adopted by 103 votes at the General Assembly of the United Nations and has been endorsed by both the World Commission for Water in the $21^{\text {st }}$ Century, and the World Commission on Dams, as well as by the International Court of Justice in the Danube case of GabcikovoNagymaros (Hungary v. Slovakia). Although the objectives of the World Water Council include "contribution to the resolution of transboundary water issues," this element has not received enough attention from the Council, and no effort was made to promote the UN Watercourses Convention.

The above summary of the situation should lead to one legitimate question: If the recurring resolutions and declarations, which are now the outcome of every global water gathering, are characterized by generalizations and include no specific monitorable actions, and if the debate on the main water issues is leading no where, then should the world community continue those elaborate and expensive water forums and conferences?

This question is certainly not easy to answer. However, it is not difficult to argue that if future resolutions and declarations are to be useful, they should concentrate on specific, monitorable, and measurable actions, such as actions to implement the goal of reducing by half, by 2015 , the proportion of people without sustainable access to safe drinking water, as well as those without basic sanitation. Such actions will need to take into account the lessons, and indeed the deficiencies, of the "International Drinking Water Supply and Sanitation Decade," such as the topbottom approach and the lack of public participation and sustainability measures. If the ministerial conferences were to be held, they should simply become reporting and discussion sessions on the actions taken, and those to be taken, to achieve the stated goals, including the millennium goal on access to water and sanitation.

The debate on the divisive issues highlighted in this article, including: dams; private sector participation; international trade on water and the human right to water; the role and responsibilities of, and the need for coordination between, the different global agencies working on water; and the modalities for cooperation on shared water resources needs to continue. However, for such a debate to be meaningful, it must be conducted in a constructive and non-ideological manner, with a view of trying to find solutions that would address the facts and concerns of each of the sides to the debate. The urgency of exploring this approach is underscored by the recent decision of the World Water Council to hold the Fourth World Water Forum in Mexico City in March 2006.

Whether the above is feasible is indeed the main challenge to the world community at large, and to the water professionals and their organizations in particular. It is the real test of our seriousness in dealing with the existing and emerging problems facing the most precious and scarce resource in the world.

\section{About the Author}

Dr. Salman M. A. Salman is Lead

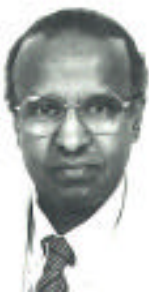
Counsel with the Legal Vice Presidency of the World Bank in Washington DC, and he is the Bank focal person on water law. Dr. Salman is a member of the Water Resources Committee of the International Law Association, and the Water Law Committee of the International Bar Association. He is also a member of the International Association of Water Law, and the World Bank Water Resources Management Group. Dr. Salman has published extensively 
in the area of national and inter-national water law, and some of his work has been translated to, and published in Arabic, Chinese, French and Russian. His recent publications include two books: Regulatory Frameworks for Dam Safety - A Comparative Study, with Professor Daniel Brad low and Dr. Alessandro Palmyra (Law, Justice, and Development Series of the World Bank, 2002); and Conflict and Cooperation on South Asia's International Rivers - A Legal Perspective, with Dr. Kishor Uprety (Kluwer Law International, 2002 and Law, Justice, and Development Series of the World Bank, 2002).

The views expressed in this article are those of the author and do not reflect the views of the World Bank or any of the organizations with which the author is associated. The author would like to thank Mr. Kishor Uprety and Ms. Siobhan McInerney-Lankford for helpful comments on an earlier draft of this article. Dr. Salman can be reached at 8448 Clover Leaf Dr. McLean, Virginia 22102, USA.Email ssalman@worldbank.org.Fax: 202-522-1573.

\section{Discussions open until September 1, 2004.}

\section{References}

Bosnjakovic, B. 1998. "UN/ECE Strategies for Protecting the Environment with Respect to International Watercourses: The Helsinki and Espoo Conventions" In S. Salman and L. Boisson de Chazournes, eds. International Watercourses Enhancing Cooperation and Managing Conflict. World Bank Technical Paper No. 414.

McCaffrey, S. 2002. The Law of International Watercourses:
Non-Navigational Uses. Oxford, UK: Oxford UP.

NEPAD. 2001. "New Partnership for Africa's Development." www.touchtech.biz/nepad/files/documents/nepad_english_ version.pdf.

Reichert, G. 2004. “The European Union Community's Water Framework Directive: A Regional Approach to the Protection and Management of Transboundary Freshwater Resources?" In L. Boisson de Chazournes and S. Salman, eds. Water Resources and International Law. The Hague: Kluwer Law International (forthcoming).

Rogers, P., and Hall A. 2003. "Effective Water Governance, Global Water Partnership.” Technical Committee Background Papers, No. 7. Sweden: Elanders Novum.

Salman, S. 2001. "Legal Regime for Use and Protection of International Watercourses in the Southern African Region: Evolution and Context." Natural Resources Journal 41, No. 4: 981-1022.

Salman, S. 2002. "The Abuja Ministerial Declaration on Water A Milestone or Just Another Statement?" Water International 27, No. 3: 442-49.

Tanzi, A., and Arcari, M. 2001. The United Nations Convention on the Law of International Watercourses - A Framework for Sharing. The Hague: Kluwer Law International.

World Water Assessment Programme. 2003. "Water for People, Water for Life." The United Nations World Water Development Report. UNESCO Publishing/Berghahn Books.

World Water Council 2003a. World Water Actions - Making Water Flow for All. Marseille, France: WWC.

World Water Council 2003b. "Financing Water for All." Report of the World Panel on Financing Water Infrastructure - Financing Water for All. Marseille, France: WWC. 